\title{
Review of "Parasitoids of insects of economic and sanitary importance collected in Brazil"
}

\author{
Carlos Henrique Marchiori
}

1 Ins tituto Federal Goiano

Diptera is one of the largest orders of insects, comprising abundant number of species as well as of individuals. Besides, these dipterous are of great medical and veterinarian importance since they may produce myiasis and may be vectors of microorganisms pathogenic to men and animals (Grennberg, 1971).

Muscoids dipterous have been found to carry diseases causing org anisms such as: bacteria, protozoa and helminthes (D'Almeida, 1992, Greenberg, 1971). Sarcophagidae are ovoviviparous insects or, rarely, viviparous (Lopes and Leite, 1989). There have been recog nized 600 species of Sarcophagidae from Neotropical region (Shewell, 1981). On the other hand, this dipterous takes relevant importance in public health, for being the vehicle of pathogenic micro-organism to human beings (Greenberg, 1971).

Fly control using insecticides usually selects resistant populations, being just a palliative. Mendes and Linhares (1993) believed that research on new methods concerning fly control is needed. Natural regulators, such as parasitoids, are agents responsible for reduction of fly populations (Mcalpine, 1981).

Among the Coreidae known to cause economic damage to crop plants, much attention has been directed to the species Leptoglossus zonatus (Dallas, 1852) (Hemiptera: Coreidae) that is abundant on maize and is considered a serious insect pest (Souza and Amaral Filho, 1999b). Leptog lossus zonatus, known in Brazil as maize bug, also feeds on several other species (14 families of fructiferous, forage and ornamental plants) showing characteristics of polyphagia and adaptation to different feeding resources (Souza and Amaral Filho, 1999a).

The insect sucks on grains and fruits inducing wilt and decay, thus reducing yield. It is more serious, however, in relation to the maize crop where losses may reach $15 \%$. This 
hemipteran has been already found in Mexico as well as in Central and South America and occurs mainly from December to April (Zucchi et al., 1993), probably influenced by the weather and available food. According to Souza and Amaral Filho (1999a), little or nothing is known about its natural enemies. No methods of population control have so far been proposed for this insect.

The caterpillars of the genus Lonomia (Lepidoptera: Saturniidae), which were collected in this experiment, are important causative agents of skin problems in humans, especially for individuals who work in rural areas. These insects can be found associated with economically important crops, which often feed and/or perform your posture (Souza and Reis, 1992). Among these pests, the tomato leaf miner Tuta absoluta (Meyrick) (Lepidoptera: Gelechiidae) stands out (Gonçalves-Gervásio et al., 1999). Tuta absoluta presents high destructive potential and may attack plant parts in all developmental stages (Souza and Reis, 1992; Michereff Filho).

The insects of the order Hymenoptera form a diverse group of approximately 200,000 species. Thanks to these insects, great savings in pest control programs have been achieved. They are mostly parasitoid organisms and, in the Neotropical region, they have been little studied and are poorly known. Hymenoptera parasitoids are the most important biological control agents and they are responsible for the majority of the economic and environmental benefits produced by biological control programs. They may provide support for biological and conservation studies. Their action on hosts increases with growth in their population and decreases with reductions in populations. The two interlinked populations fluctuate in relation to each other in such a way as to impede both abrupt increases and the extinction of the host population (Gauld and Bolton, 1988; La Salle and Gauld, 1991; Scatolini and Penteado-Dias, 1997).

Interest in biological controls has grown in various countries, as a response to the adverse effects of chemical pesticides on the environment and on biodiversity. Moreover, it has grown as a function of new international trends in agricultural production involving the utilization of alternative means that are less aggressive to the environment and which favor conservation and the sustainable use of biodiversity (Scatolini and Penteado-Dias, 1997; Marchiori and Dias, 2002).

Since parasitoids occupy a superior trophic level, they act as determining factors on the population densities of their hosts due to the diversity of their physiological and behavioral adaptations (Gauld and Bolton, 1988) (Figure 1). 


\section{REFERENCES}

D'Almeida, J. M. Calyptrate Diptera (Muscidae and Anthomyiidae) of the State of Rio de Janeiro - I. Synanthropy. Memórias do Instituto Oswaldo Cruz, v.87, p. 381-386, 1992. Gauld, I. D. and Bolton, B., 1988, The Hymenoptera. Oxford University Press, Oxford, 33p.

Greenberg, B. Flies and disease - ecology, classification and biotic association. New Jersey: Princeton Univ. Press, 1971. 447p.

Gonçalves-Gervásio R.C.R.G., Ciociola A.I, Santa Cecîlia L.V.C., Maluf, W.R. 1999. Aspectos biológicos de Tuta absoluta (Meyrick, 1917) (Lepidoptera: Gelechiidae) em dois genótipos de tomateiro contrastantes quanto ao teor de 2-tridecanona nos folíolos. Cienc Agrotec 23: 247-251.

Hanson, P. E. and Gauld, I. D. (1995). The Hymenoptera of Costa Rica. Oxford, Oxford Univ. Press. 893p.

La Salle, J. and Gauld, I. D., 1992, Parasitic Hymenoptera and biodiversity crisis. Redia. 74: 315-334, 1992.

Lopes, H.S.; Leite, A.C.R.. Morphology of the egg of Sarcodexia lambens (Diptera: Sarcophagidae). Memórias do Instituto Oswaldo Cruz, v.84, p.497-500, 1989. Marchiori, C. H.; Dias, A. M. P. (2002). Famílias de parasitóides coletadas em área de mata e pastagens no município de Itumbiara, Estado de Goiás. Acta Scientiarum, 24, 897-899.

Mcalpine, J.E.; Peterson, B.V.; Sheweell, G.E.; Teskey, H.J.; Vockroth, J. R.; Wood, D.M. Manual of neartic Diptera. Otawa: Research Branche Agriculture Canada, Otawa, Canadá, 1981. 1332 p.

Michereff Filho M., Vilela E.F. 2000. Traça-dotomateiro, T uta absoluta (Lepidoptera: Gelechiidae). pp. 81-84. In: Vilela E. F. Zucchi R.A., Cantor, F. (eds.), Pragas introduzidas. Holos Editora, São Paulo, Brasil.

Shewell, G.E. Sarcophagidae. In: Mcalpine, J.E.; Peterson, B.V.; Sheweell, G.E.; Teskey, H.J.; Vockroth, J. R.; Wood, D.M. Manual of neartic Diptera. Otawa: Research Branche Agriculture Canada, 1981. p.1159-1186.

Scatolini, D.; Penteado-Dias, A. M., Fauna de Braconidae (Hymenoptera) Como bioindicadora do grau de preservação de duas localidades do Estado do Paraná. Rev. Brás. Ecol., 1:84-87, 1997.

Souza, E. P.; Amaral Filho, B. F. 1999a. Nova Planta hospedeira de Leptoglossus zonatus (Dallas) (Heteroptera: Coreidae). An. Soc. Entomol. Brasil, 28: 753: 755.

Souza, E. P.; Amaral Filho, B. F. 1999b. Ocorrência natural de parasitóides de Leptoglossus zonatus (Dallas) (Heteroptera: Coreidae). An. Soc. Entomol. Brasil, 28: 
757:759.

Souza J.B., Reis, P.R. 1992. Traça-do-tomateiro: histórico, reconhecimento, biologia, prejuízos e controle. Epamig, Lavras, 20p

Zucchi, R. A.; Neto, S. S.; Nakano, O. 1993. Guia de identificação de pragas agrícolas. $5^{a}$

Ed. Fealq, Piracicaba, 139 pp.

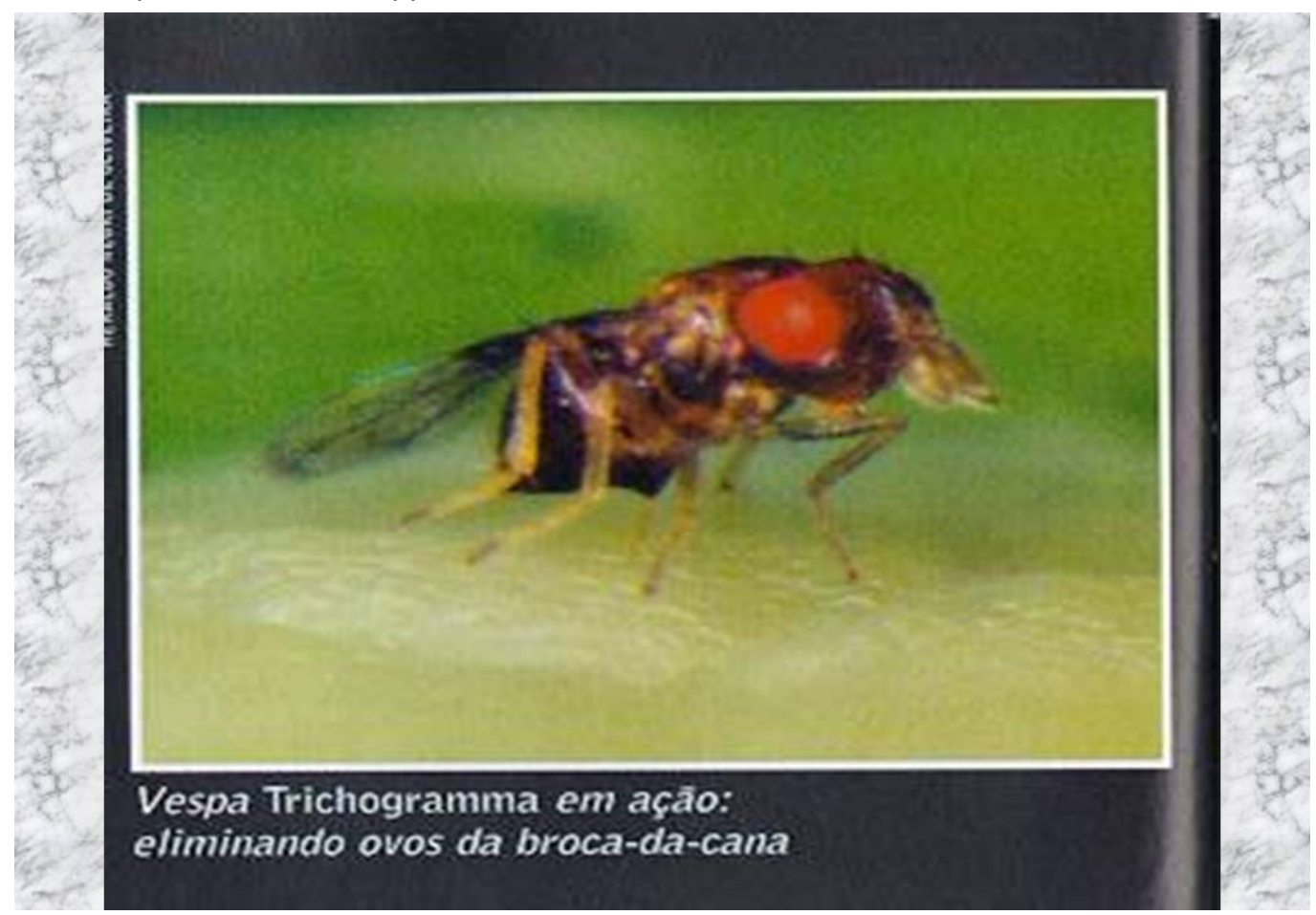

Caption

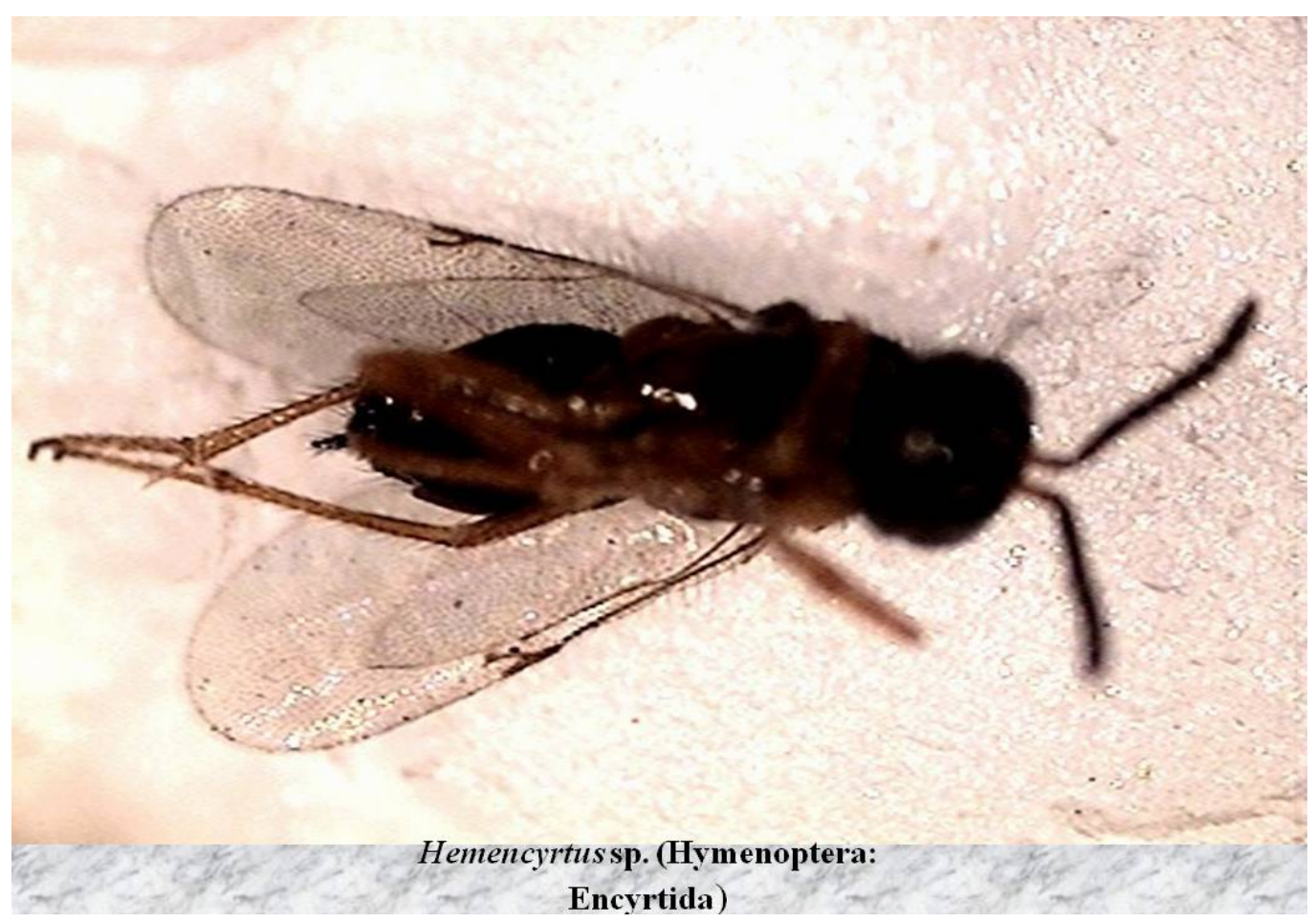

Caption 


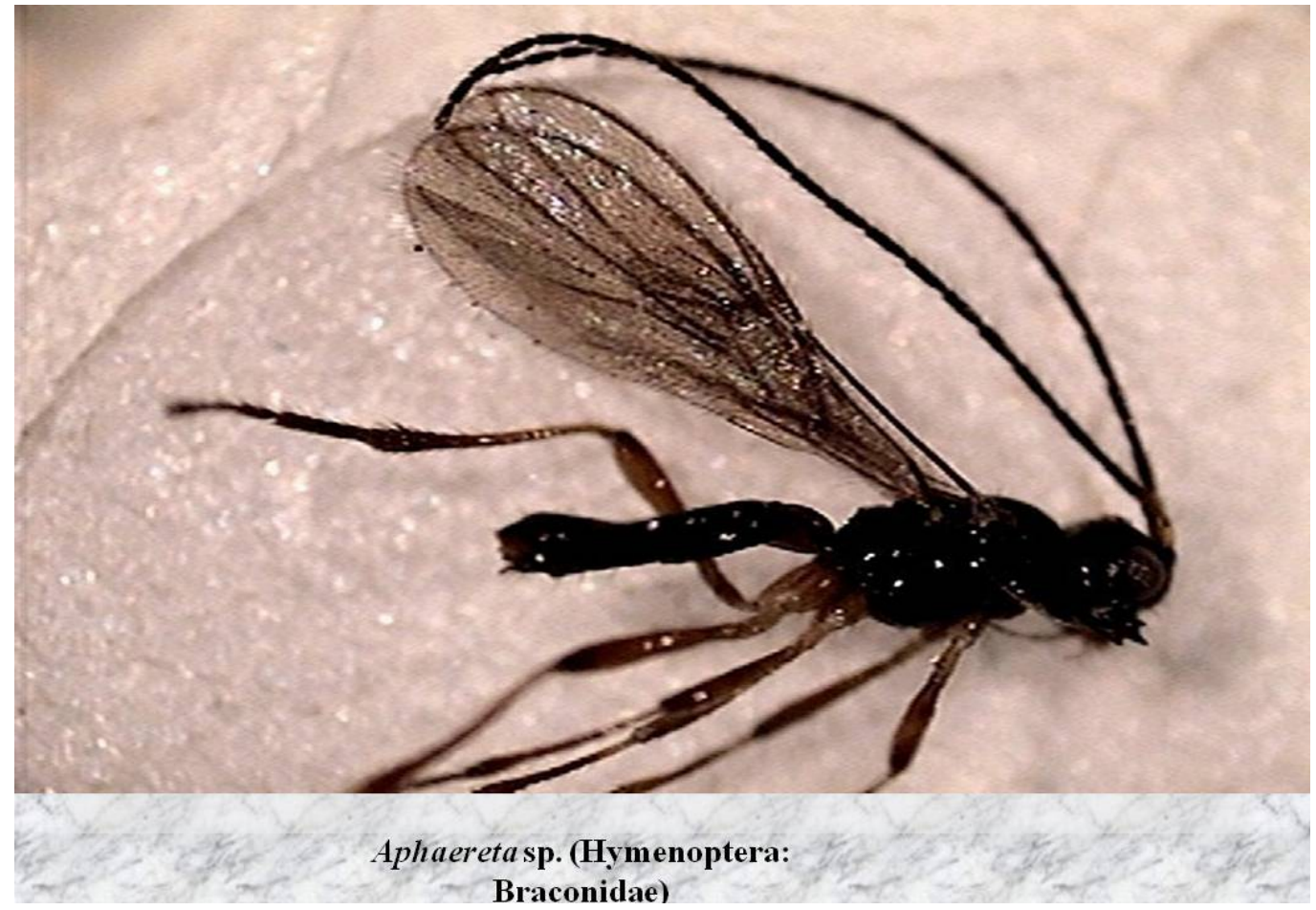

Caption

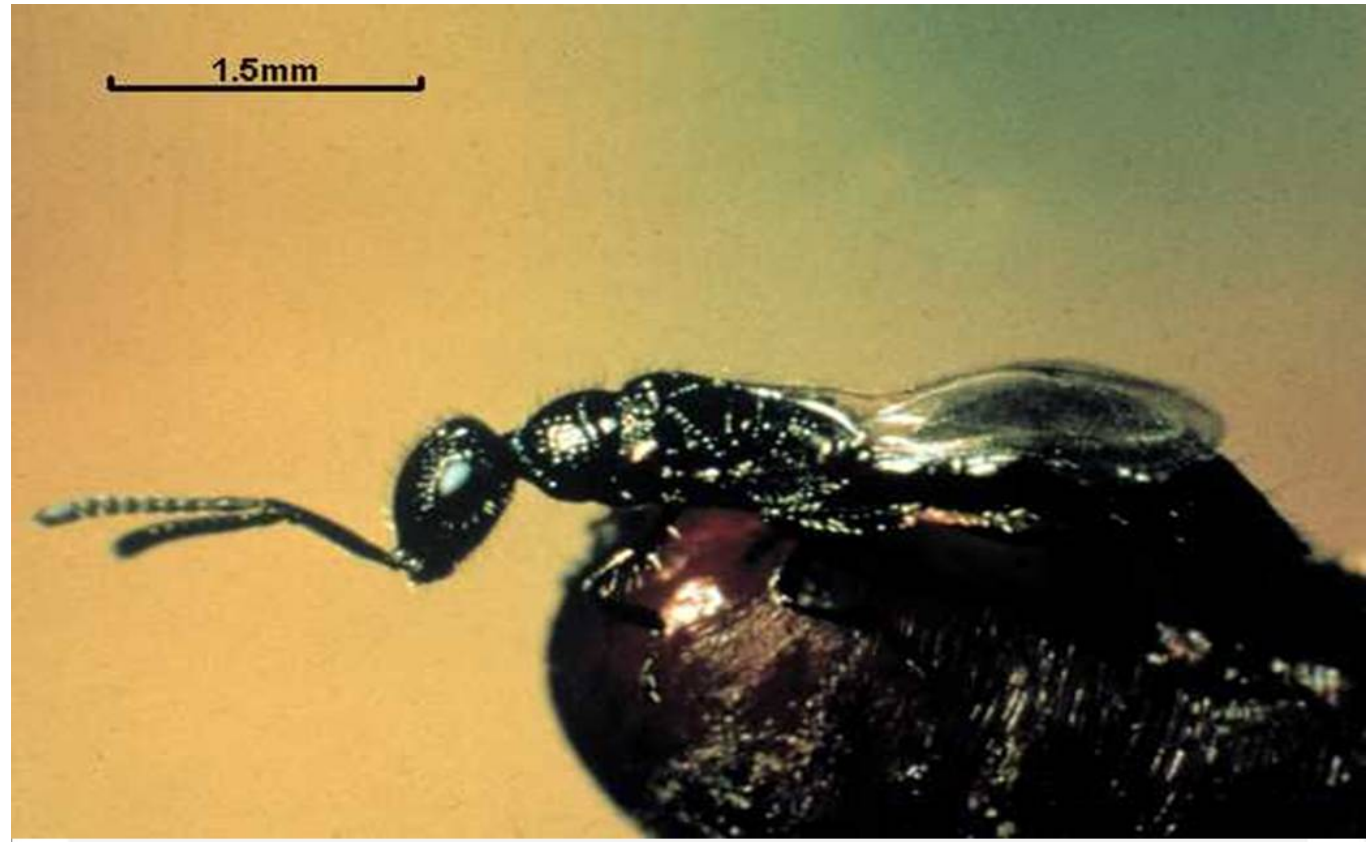

Spalangia endius (Walker) (Pteromalidae)

Caption 


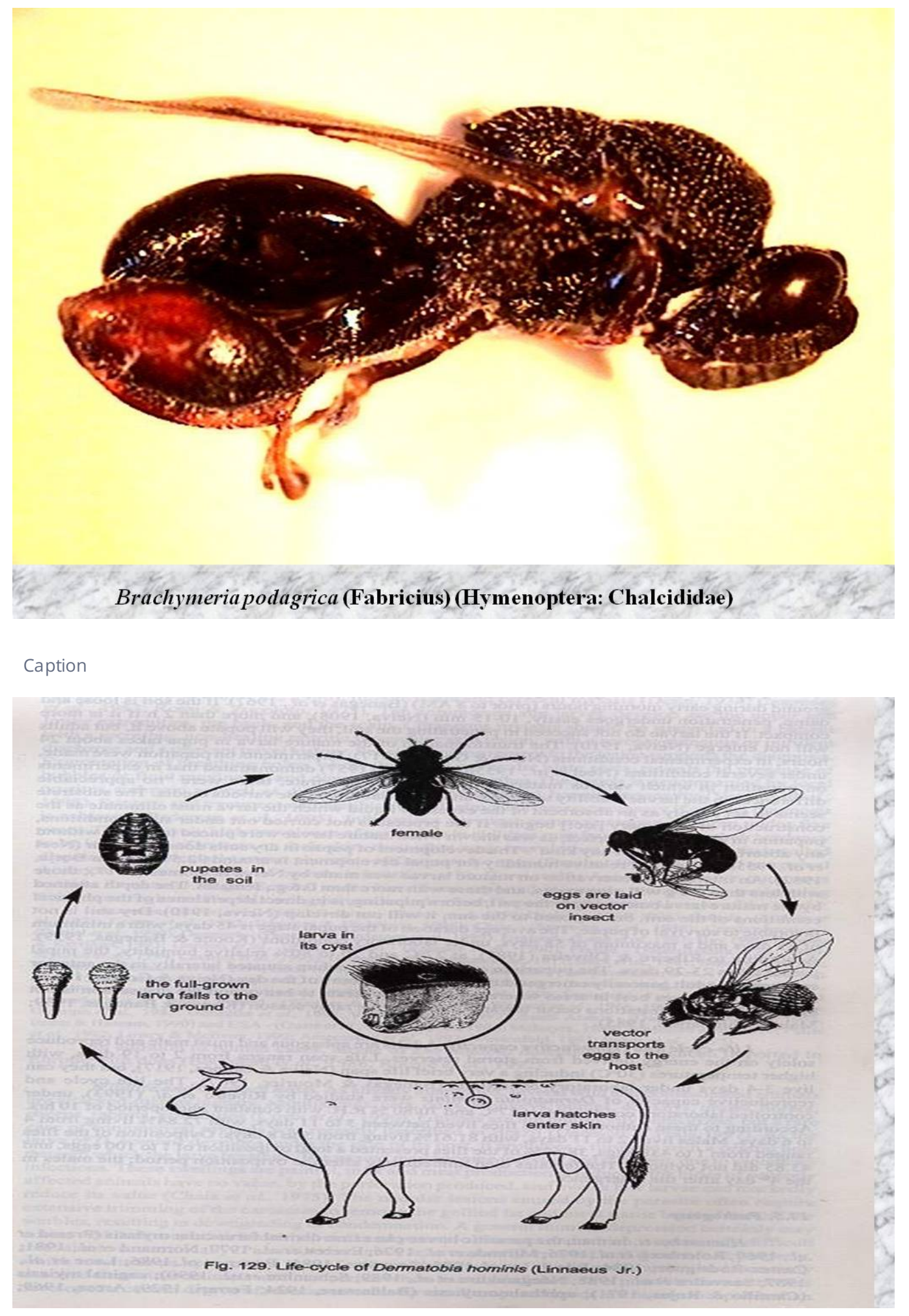

Caption 


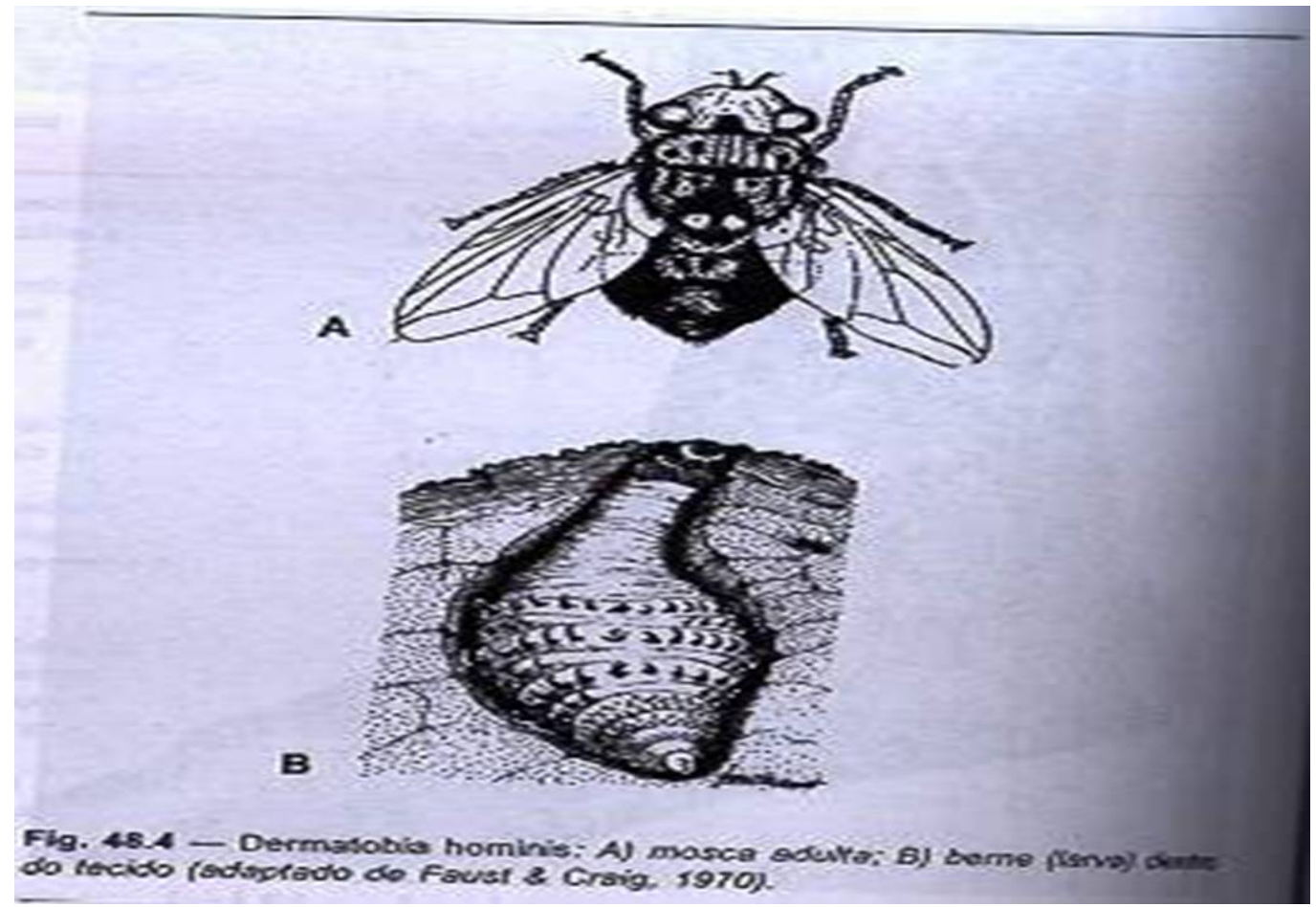

Caption

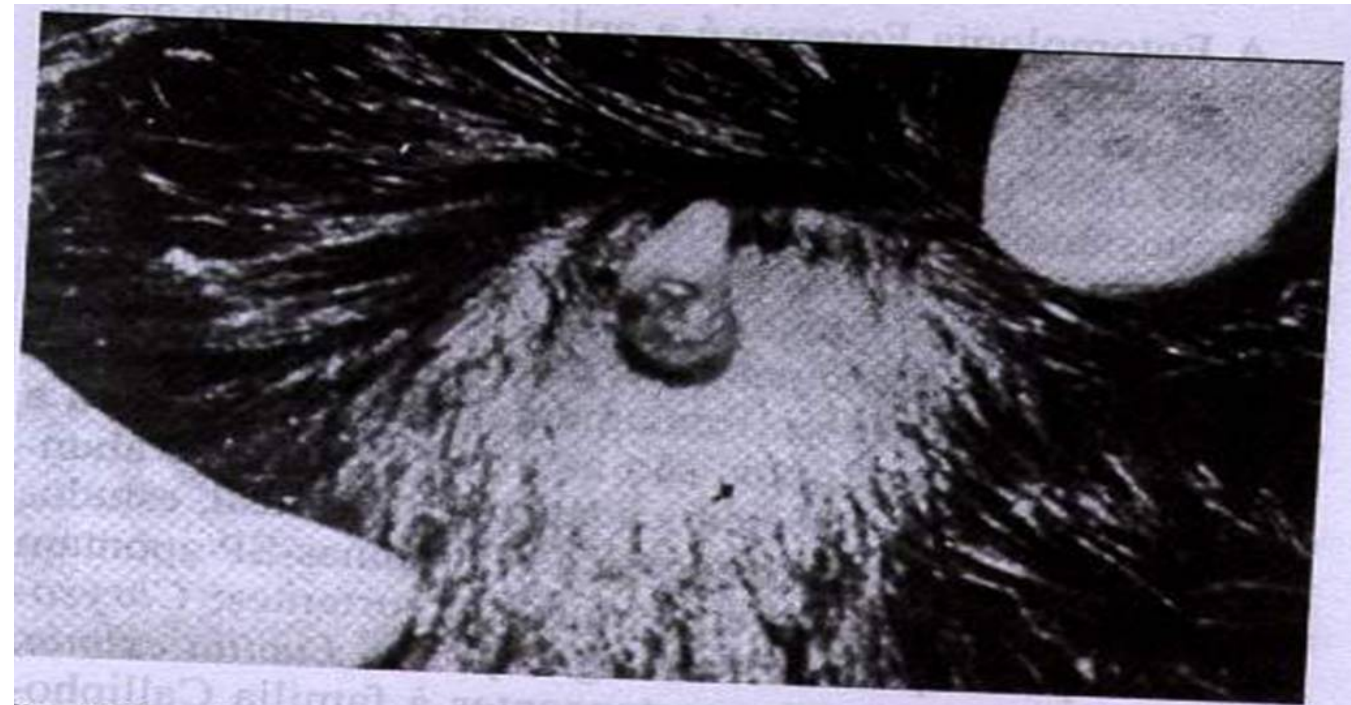

ig. 48.6 - Miiase provocada pela larva de Dermatobia hominis; notar que or tamponação do expulso por compressão manual, após ter sido morto chering das de orificio com esparadrapo ou vaselina (segundo Atlas chering das Dermatoses Tropicais - $n^{2} 3$ - Doenças Parasitárias). 


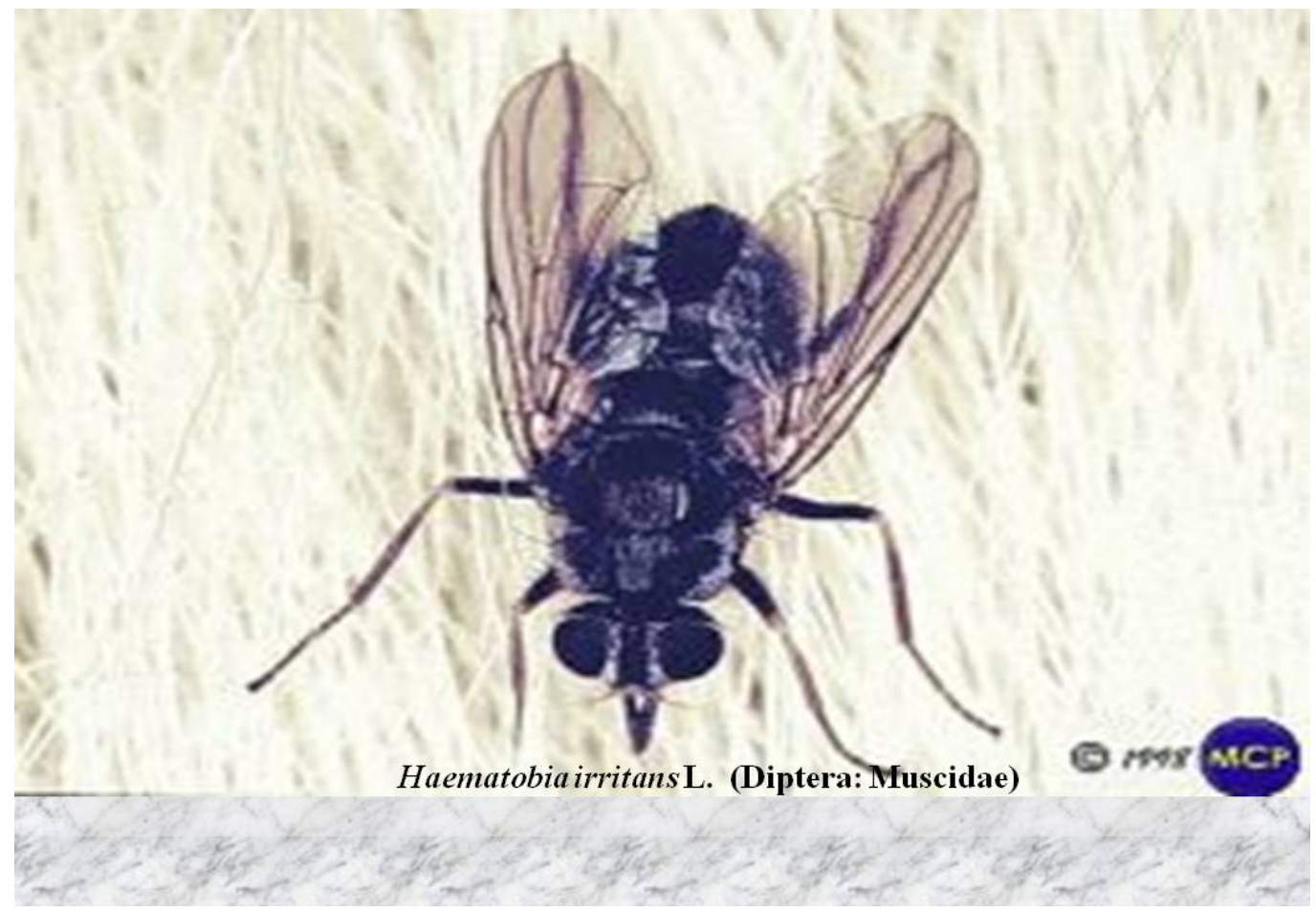

Caption

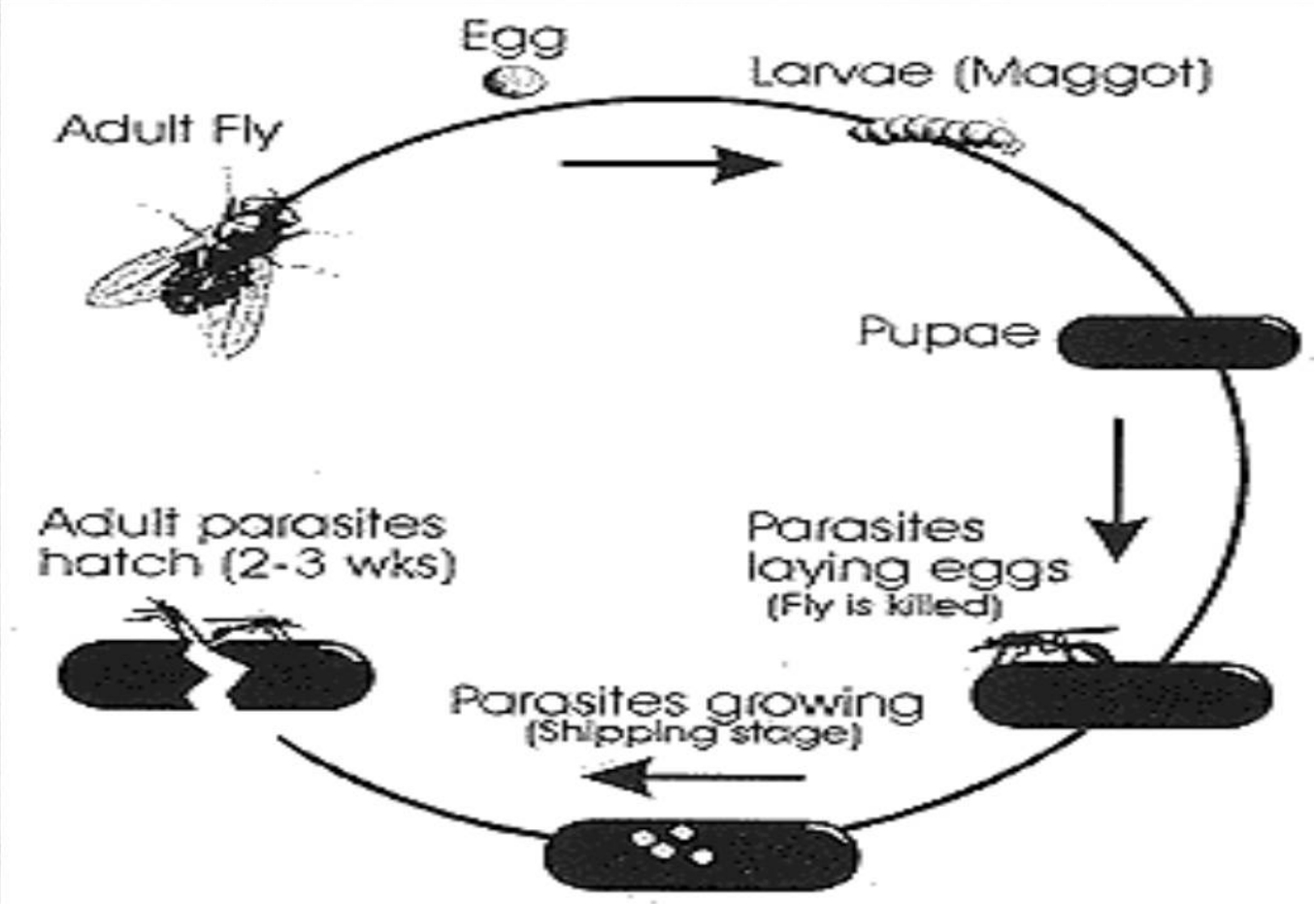

Caption 


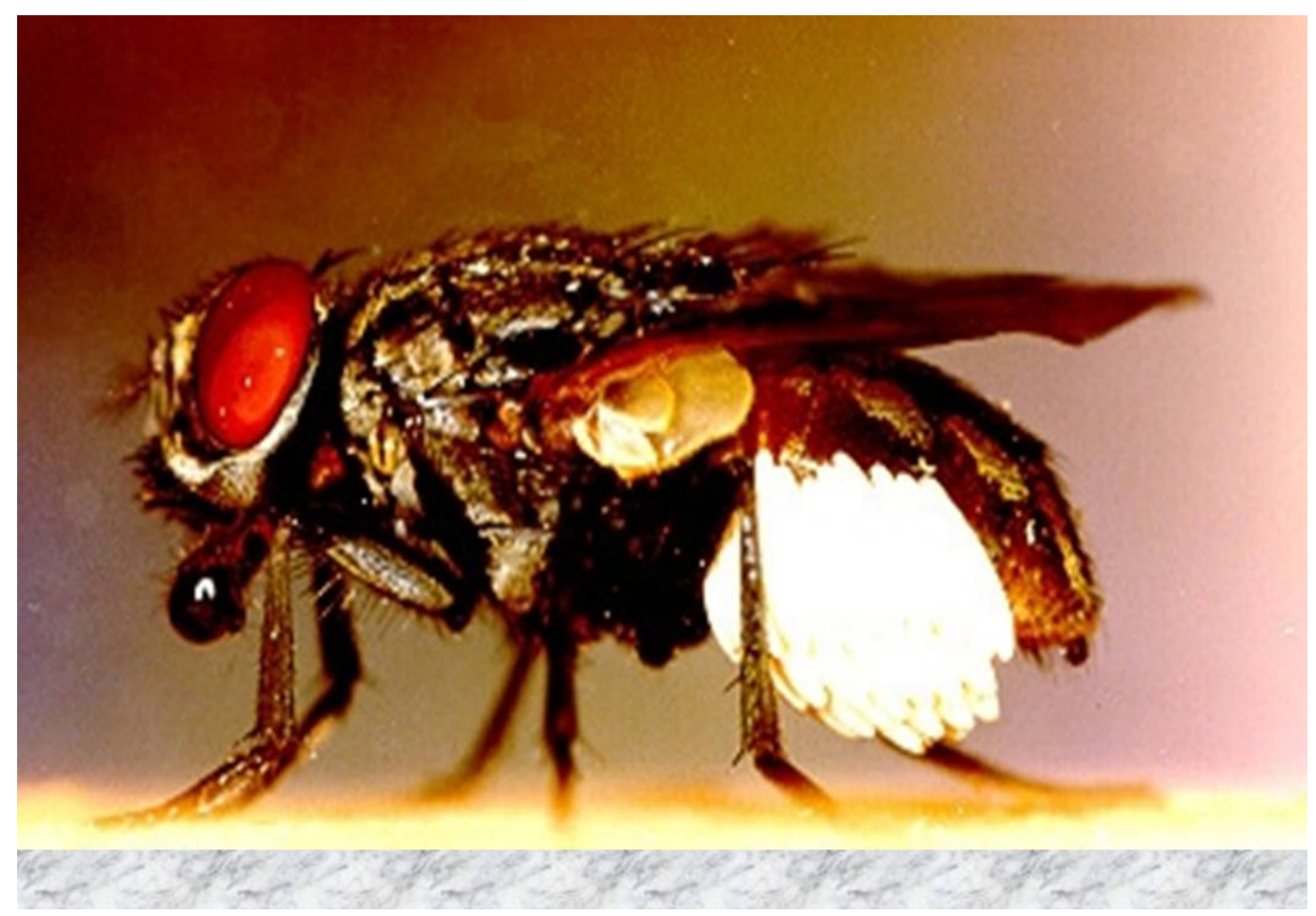

Caption

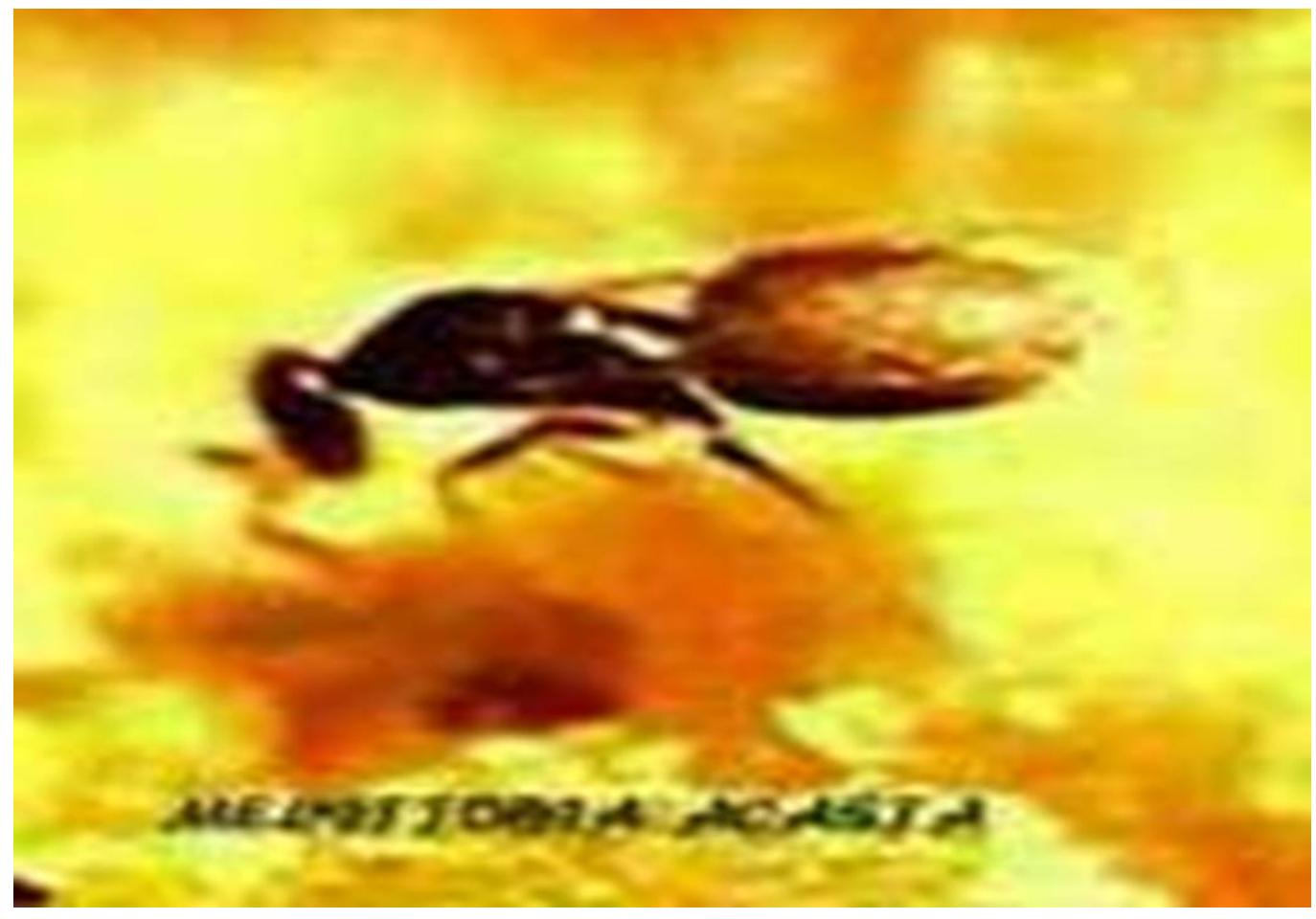

Caption 


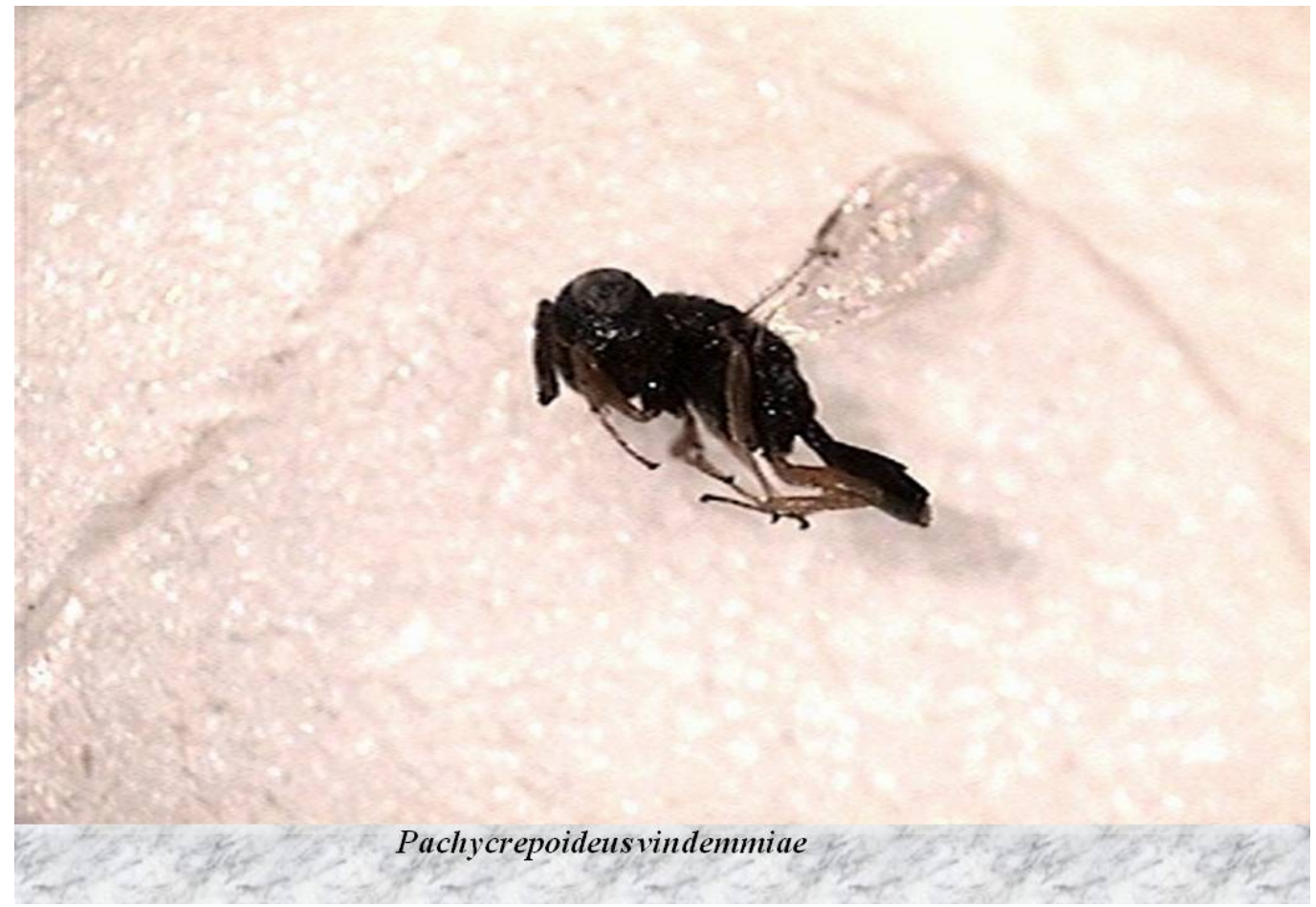

Caption

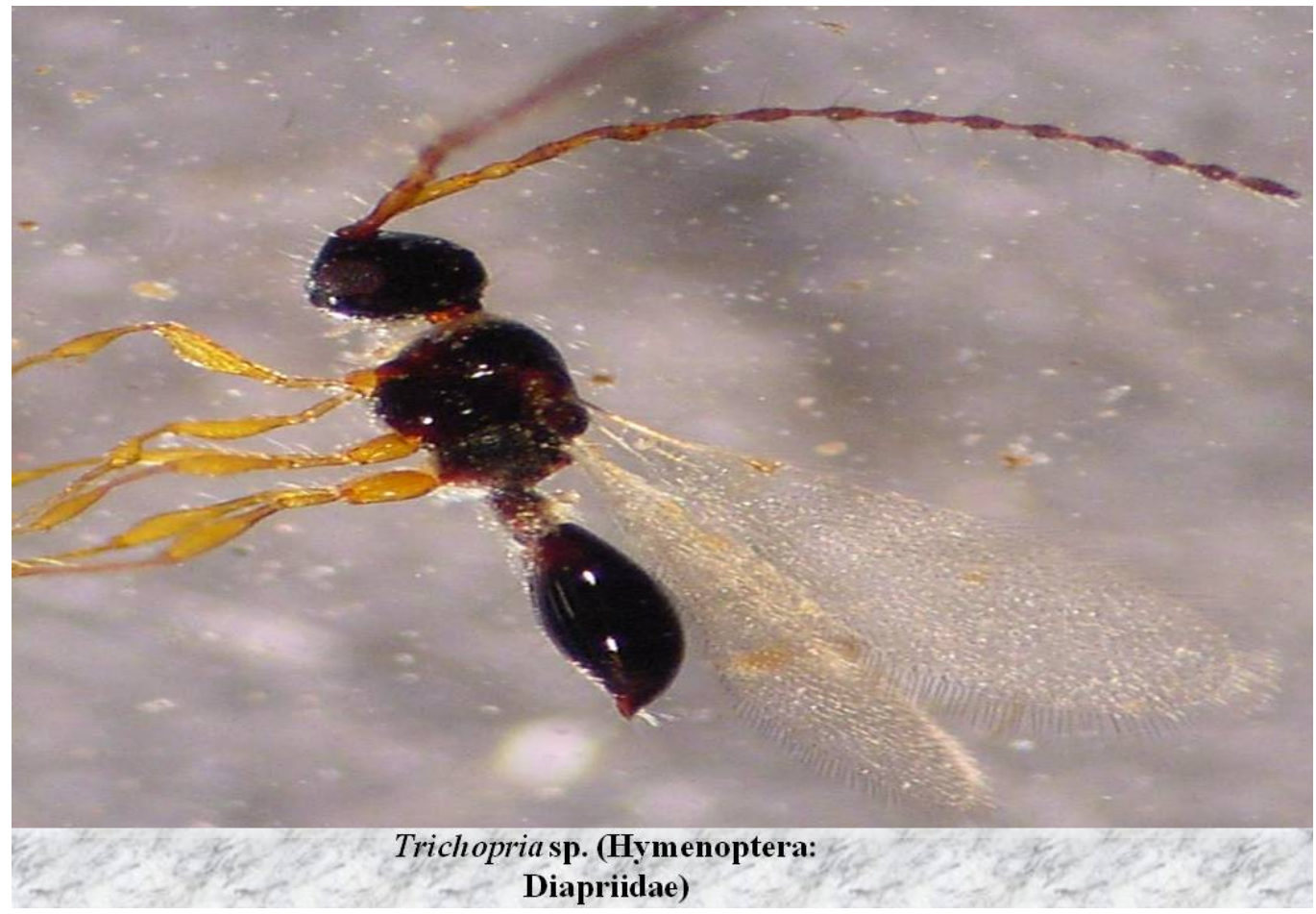

Caption 


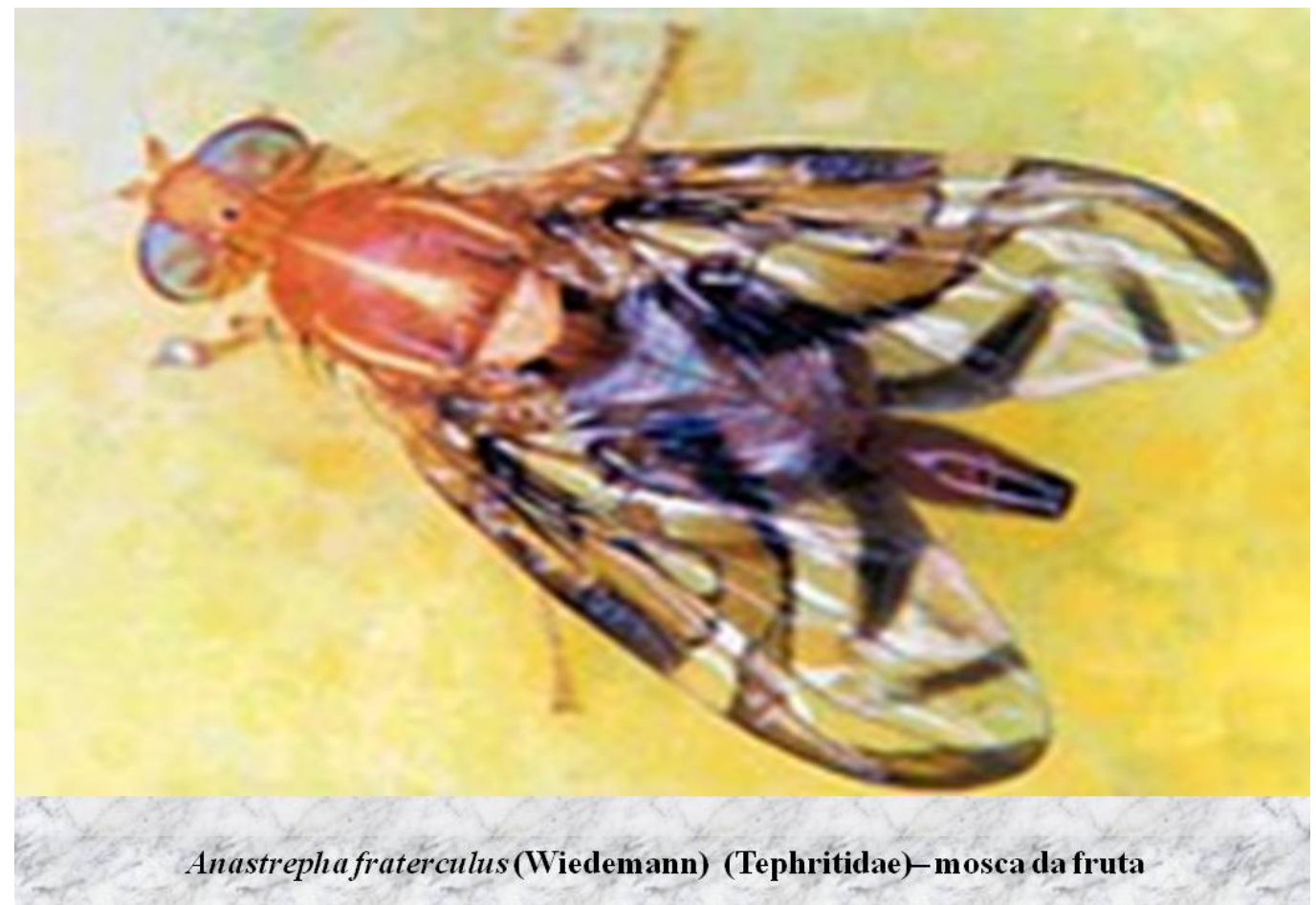

Caption

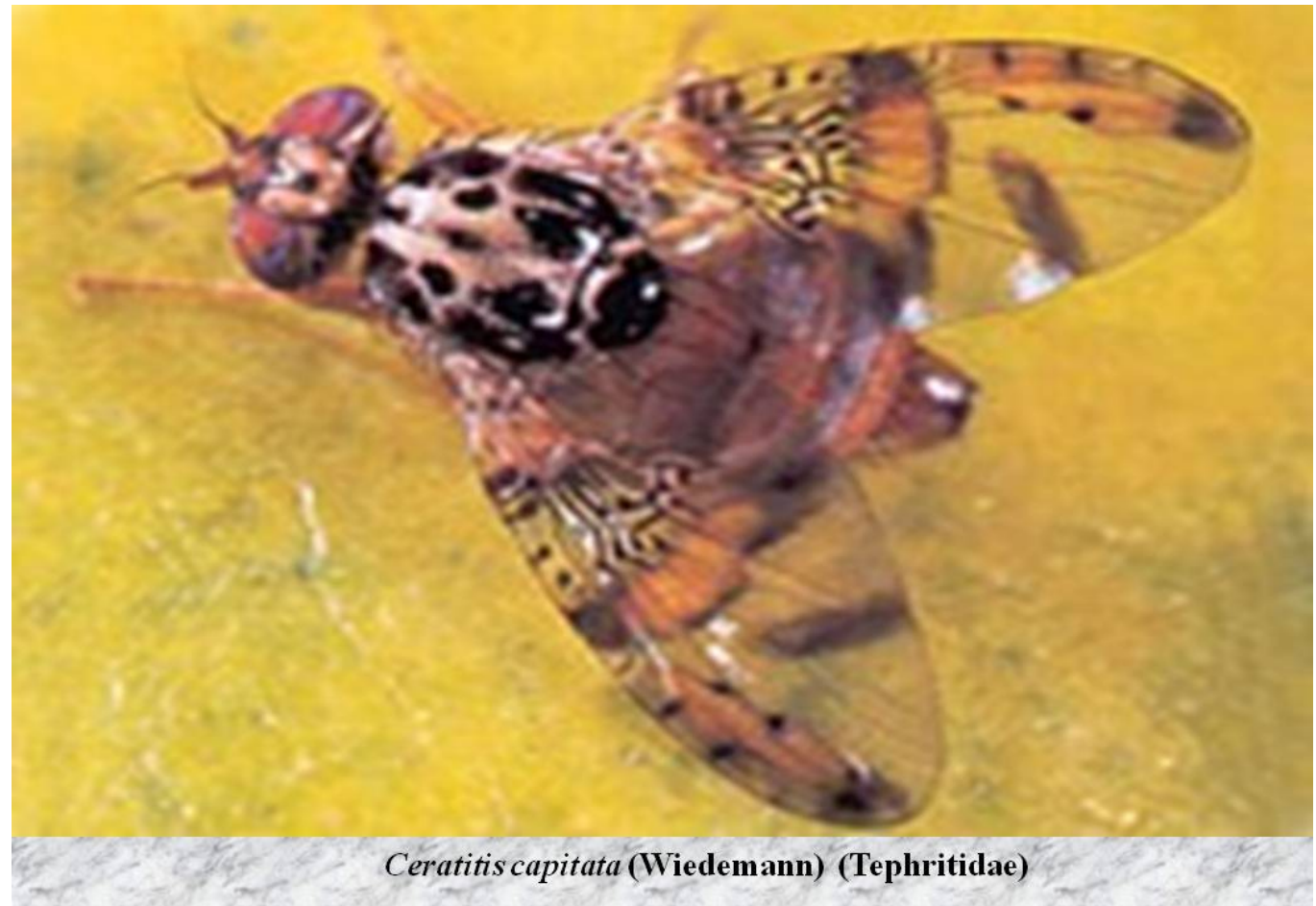

Caption 


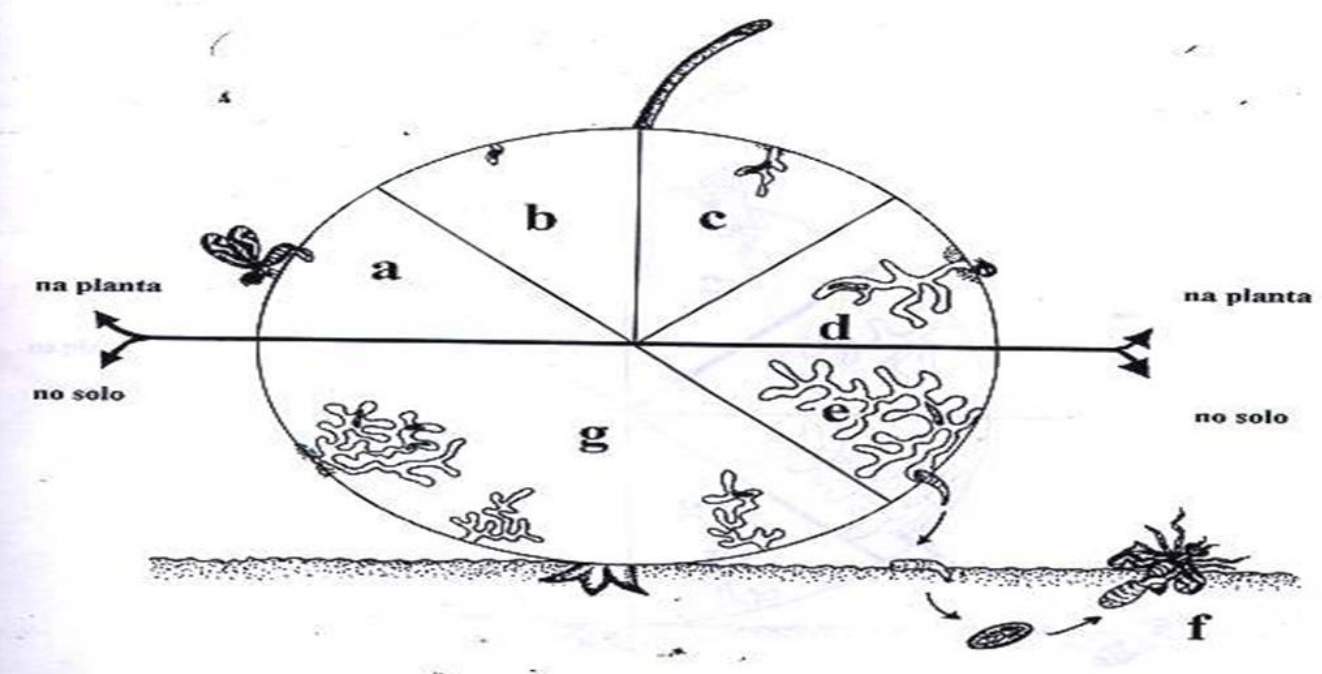

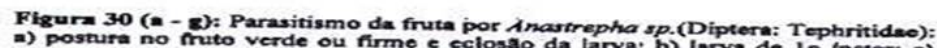

a) postura no muto verde ou firmo e eclosto da larva: b) larva de lo instart; e) Iarva de 20 mo final do 20 instar que sai da fruta o se enterra no solo, onde empupa; fo emergencia da

Caption

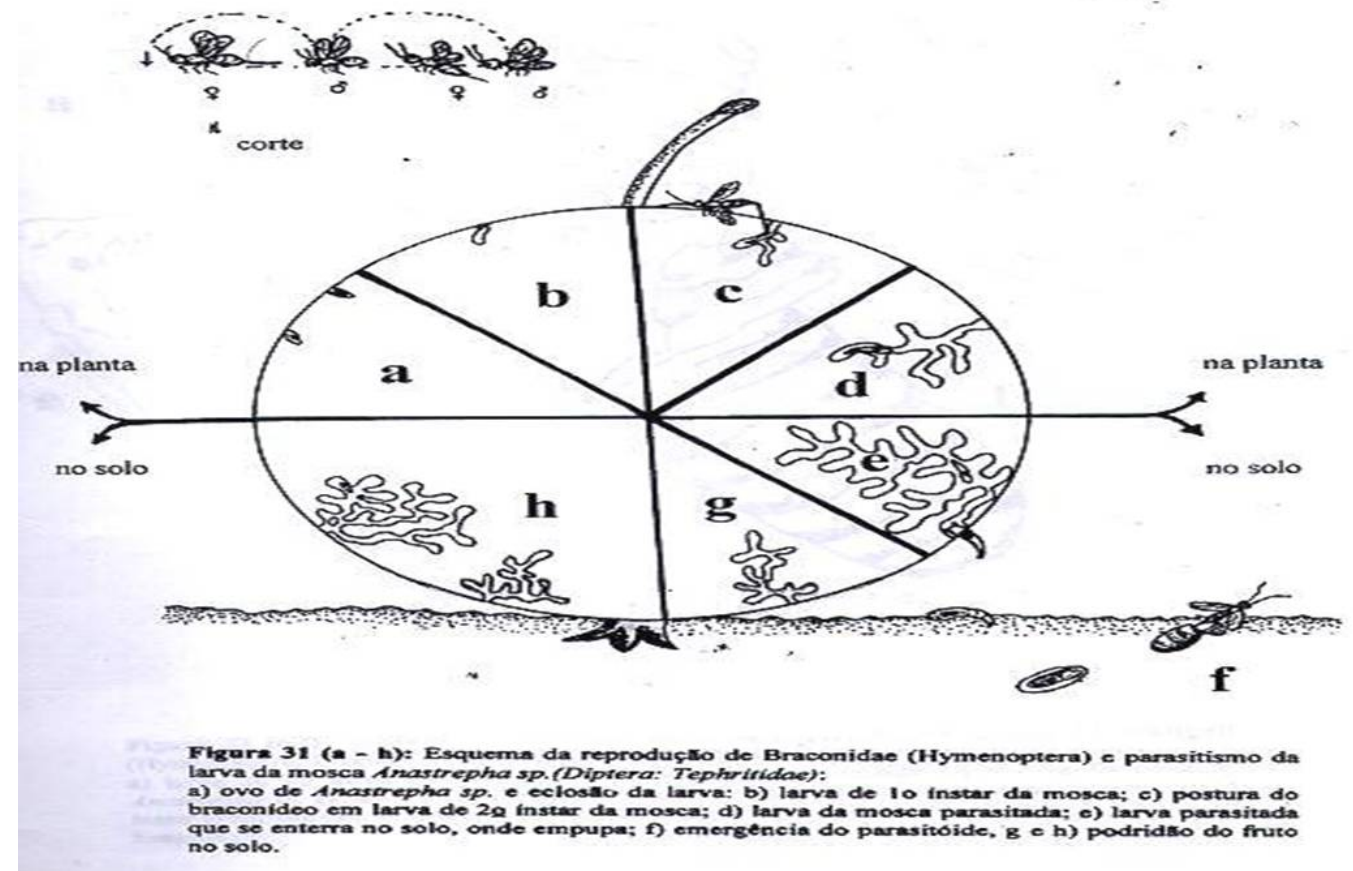

Caption 


\section{Zaprionusindianus Gupta (Diptera:} Drosophilidae)

\section{Caption}

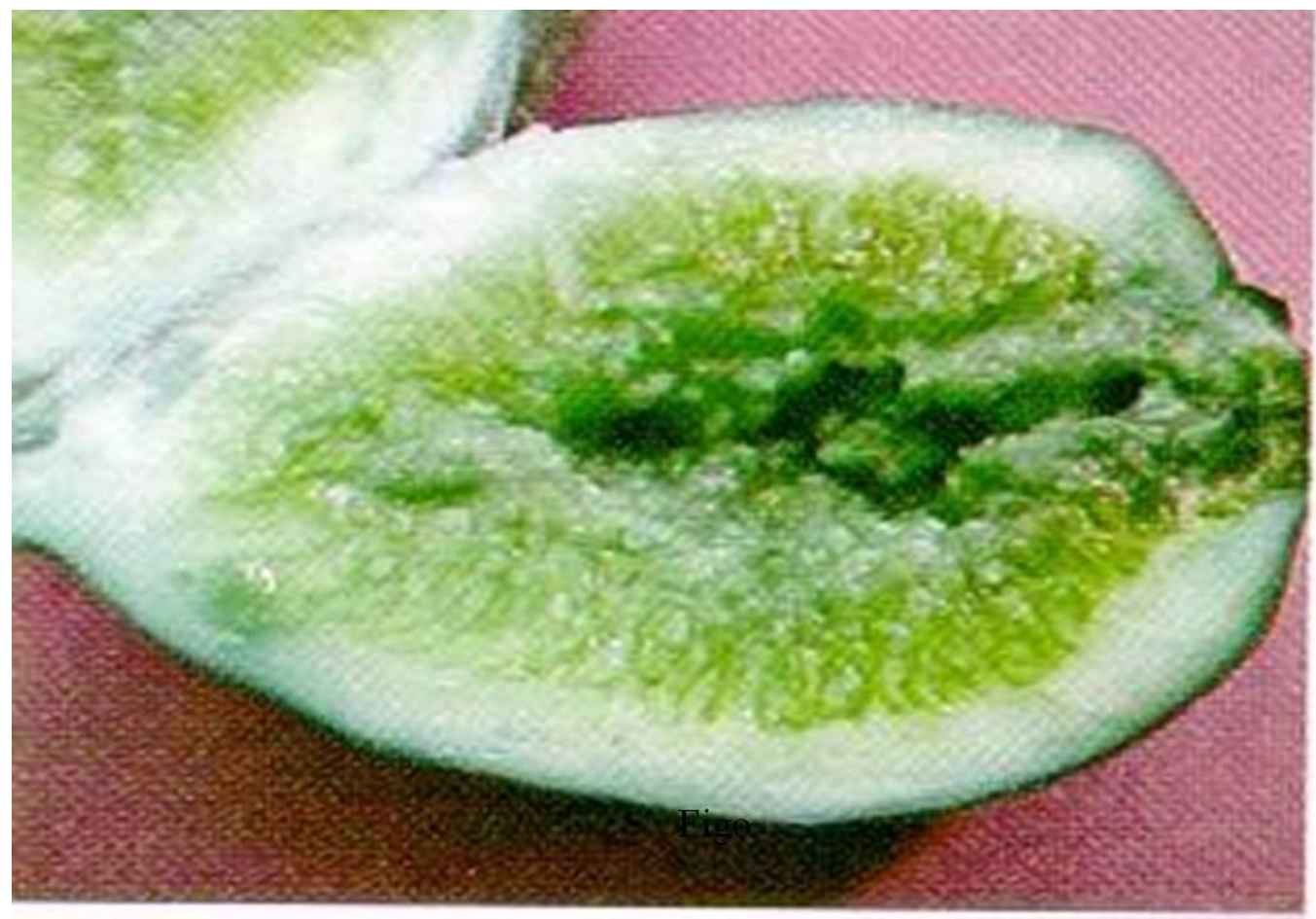

Caption 

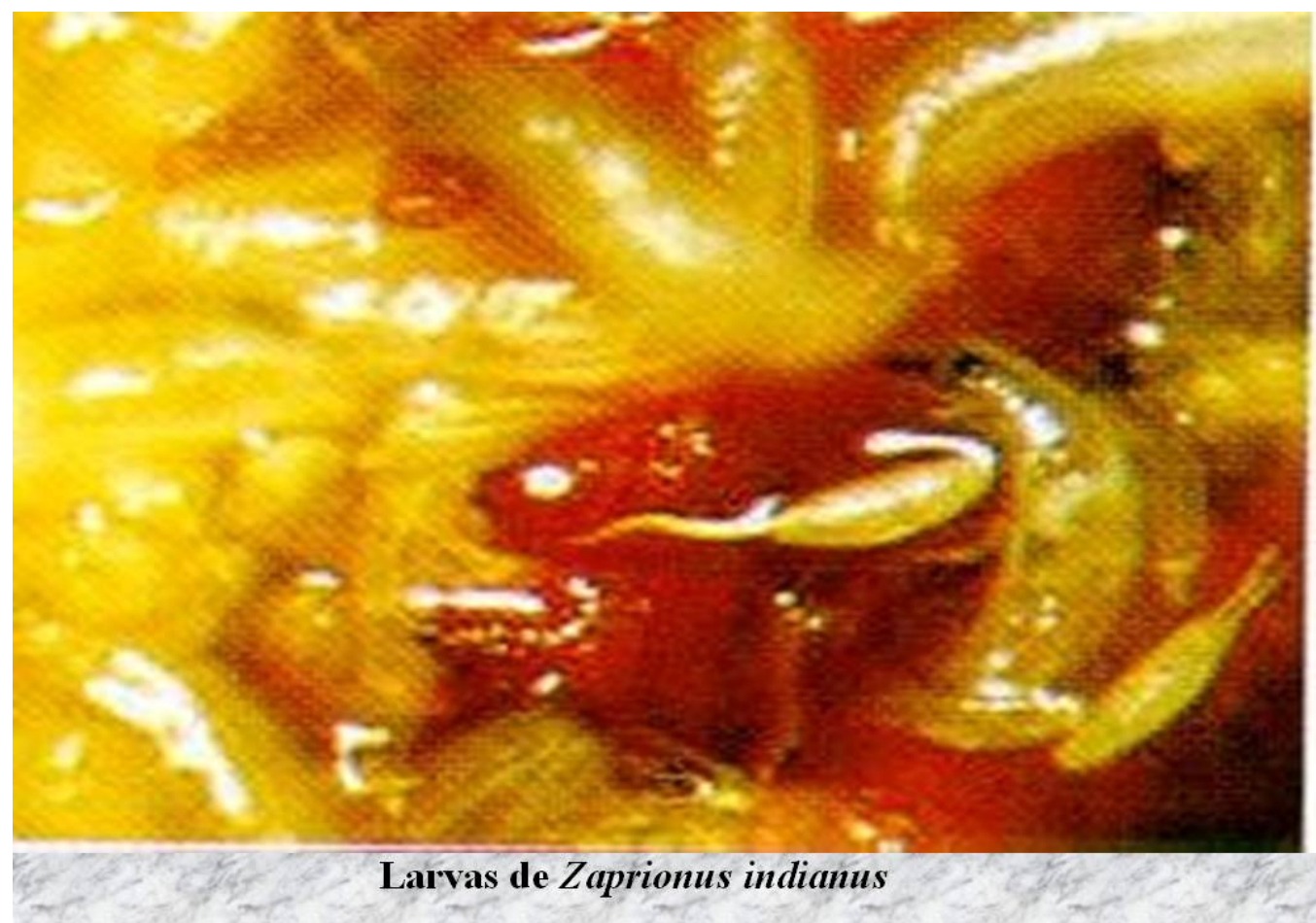

Caption

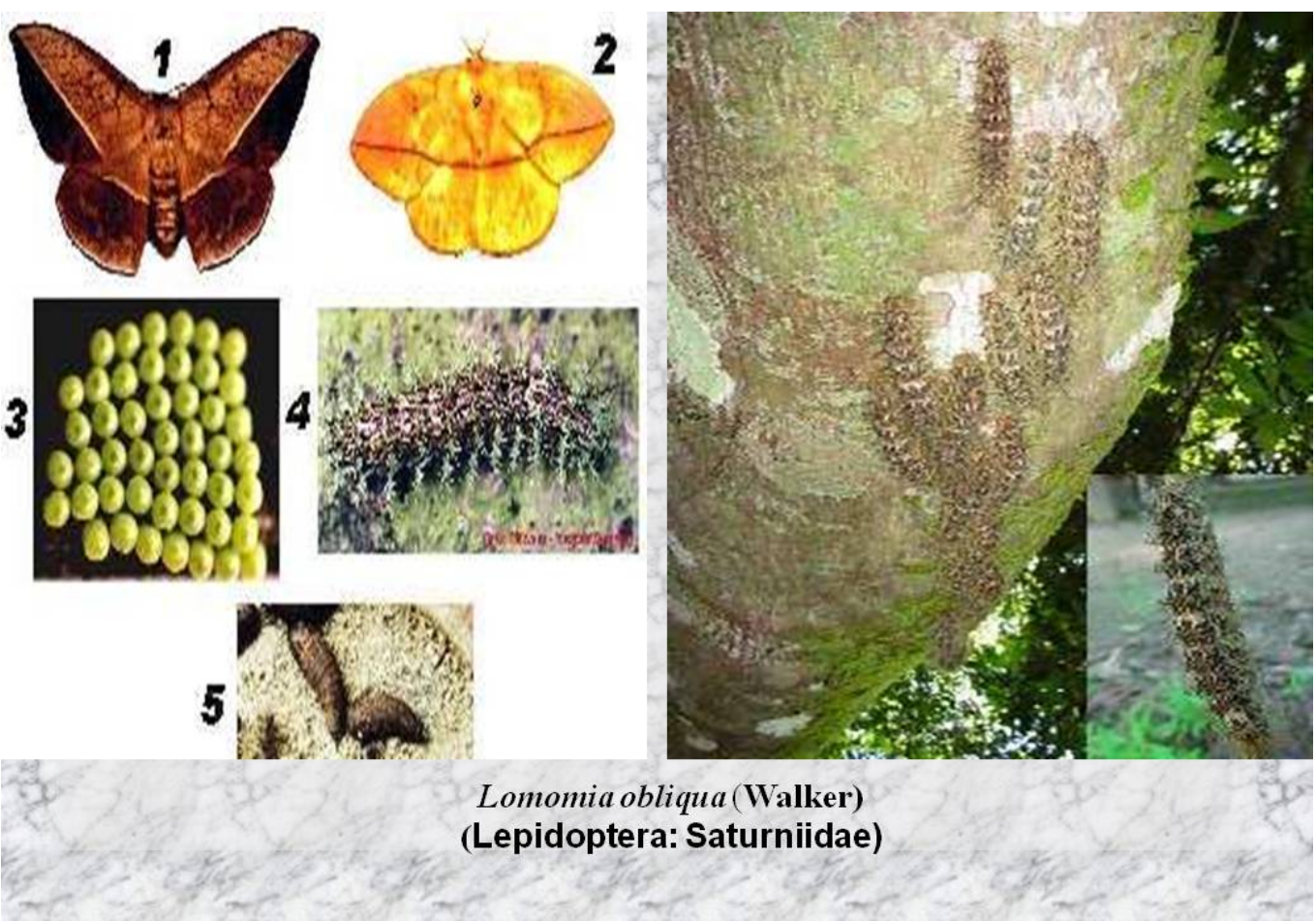

Caption 


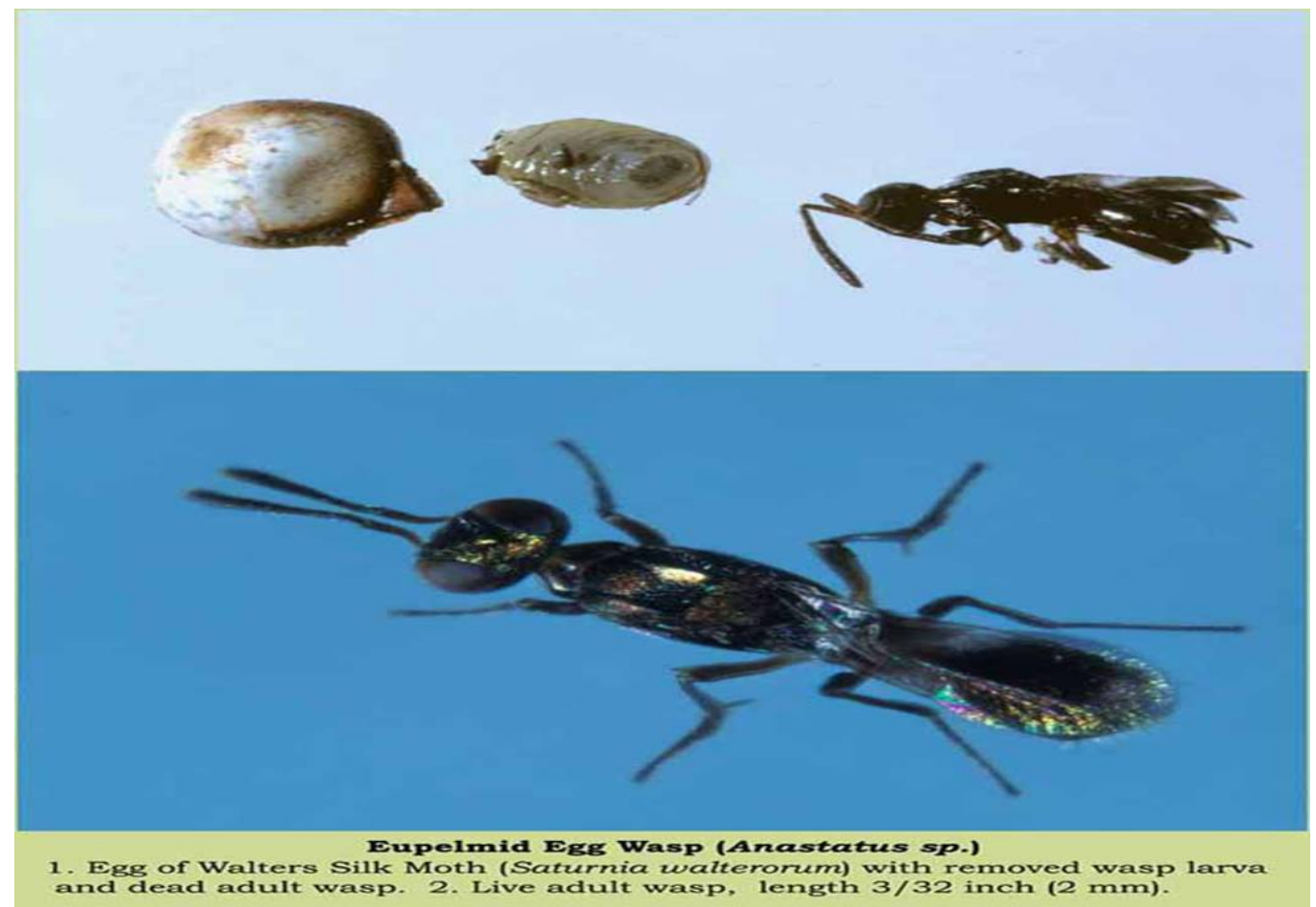

Caption

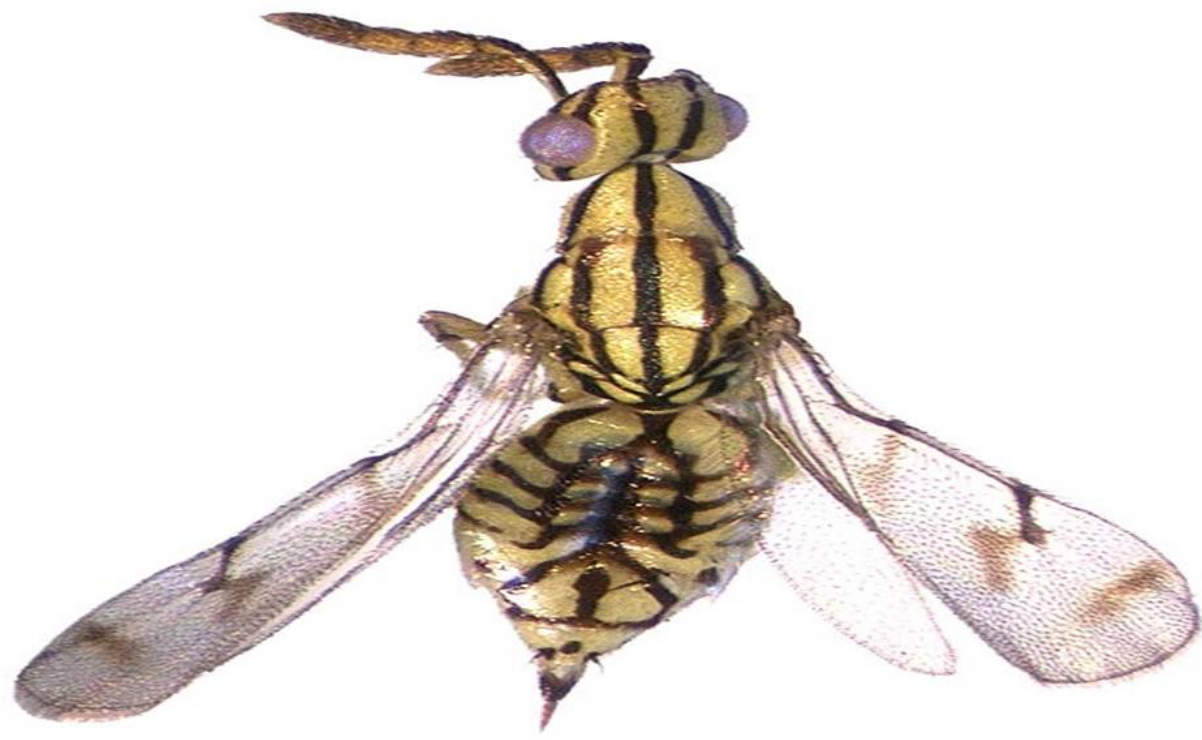

\section{Aprostocetus sp. (Hymenoptera:} Eulophidae) (ataca larva)

Caption 


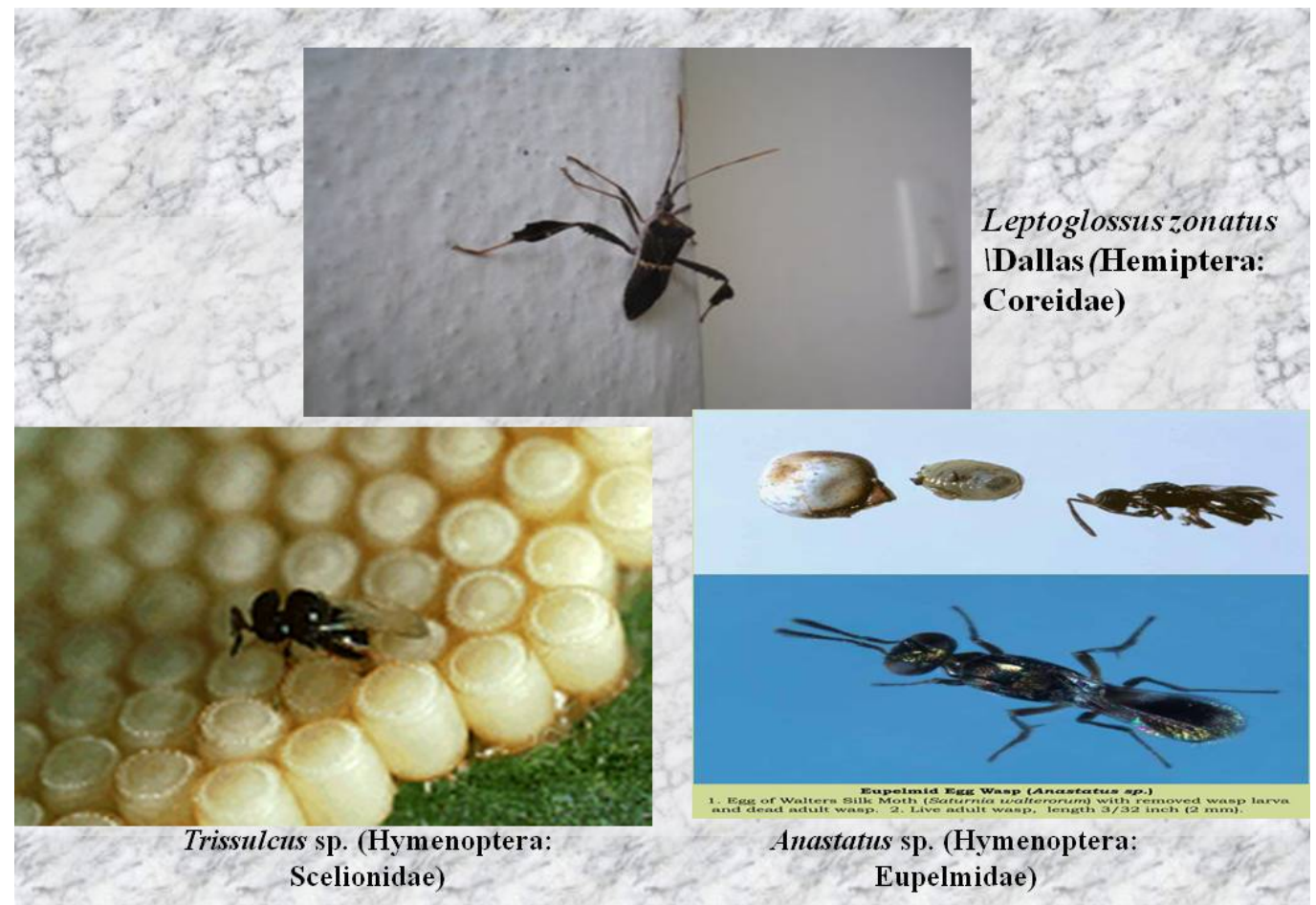

Caption
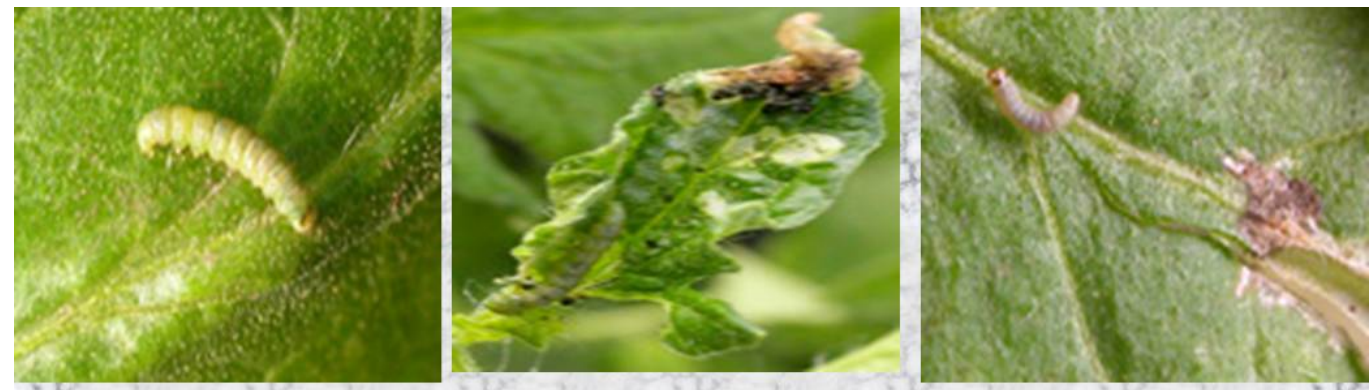

Tuta absoluta (Meyrick) (Lepidoptera: Gelechiidae)

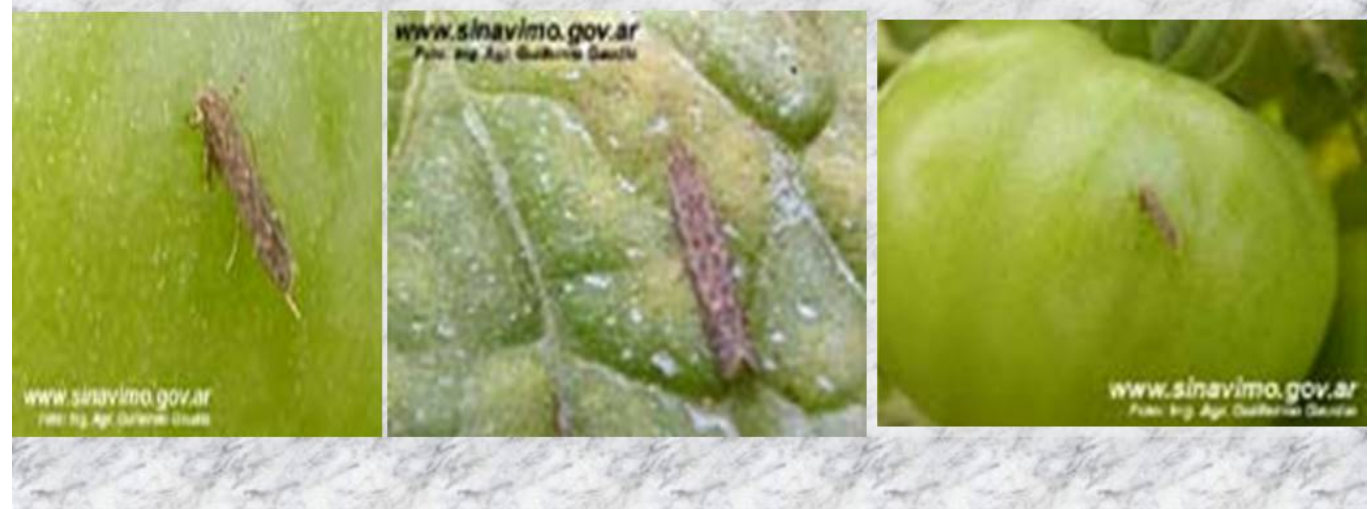

Caption 


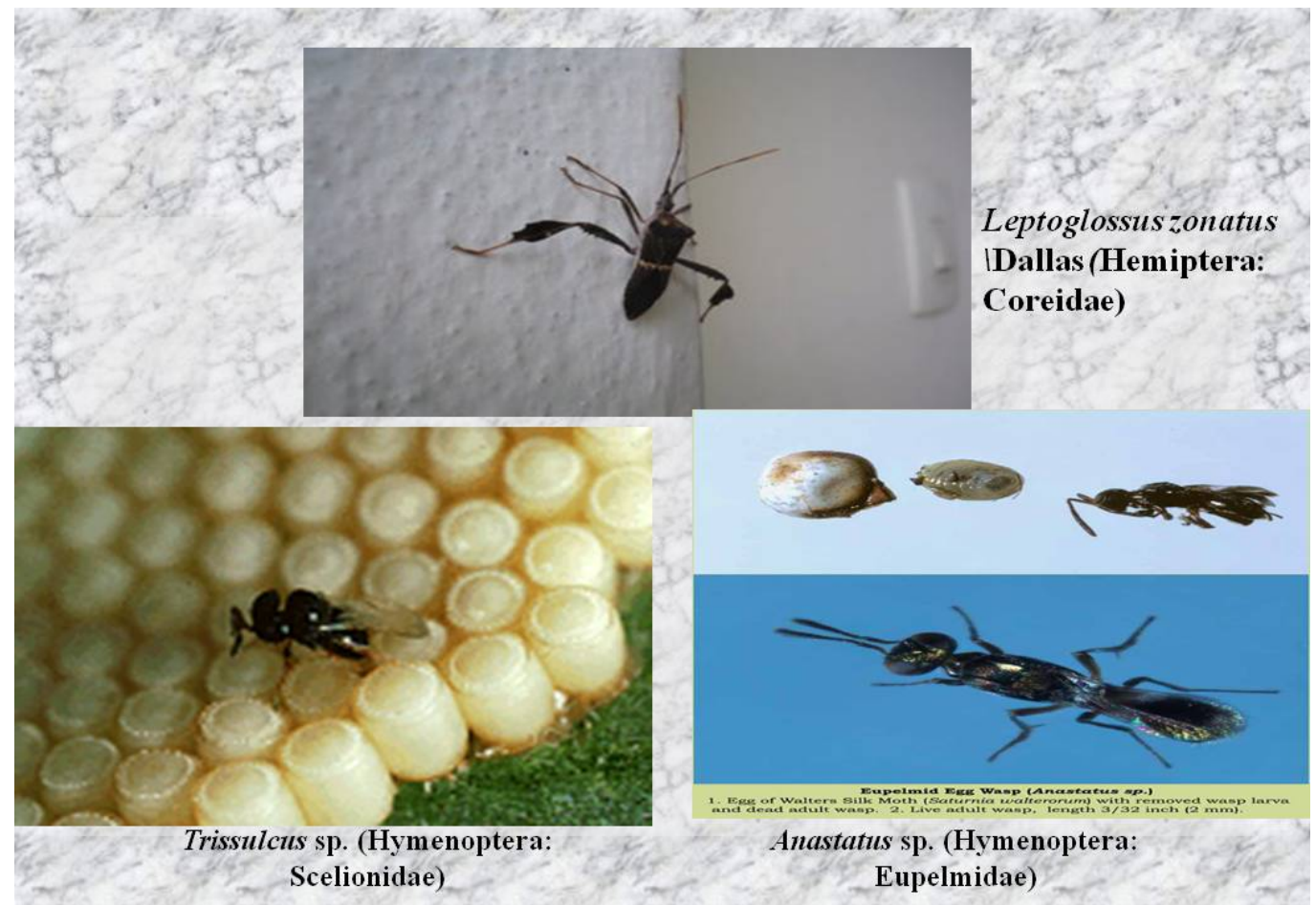

Caption 